\title{
IDENTIFIKASI BENTUK PERUNDUNGAN (BULLYING ) DI SMP NEGERI 5 TELUK ELPAPUTIH
}

\author{
Falantino Eryk Latupapua, Sarleoky N. Umkeketony, \\ Revannry Th. Rehatta, M. Farik Soumena, Fadly Tuhepaly
}

Pendidikan Bahasa dan Sastra Indonesia, FKIP Universitas Pattimura, falantinoeryk2@gmail.com

\begin{abstract}
Abstrak: Perundungan atau bullying sering terjadi di lingkungan persekolahan, baik dilakukan secara sadar maupun tidak sadar, baik direncanakan maupun tidak direncanakan. Dalam konteks kelompok masyarakat Maluku, hal itu turut terlestarikan dengan adanya budaya basengaja sebagai prasyarat penerimaan dalam lingkungan sosial, termasuk lingkungan persekolahan di Maluku Tengah. Dengan demikian, kegiatan Pengabdian Kepada Masyarakat ini dilaksanakan di SMP Negeri 5 Teluk Elpaputih, Kabupaten Maluku Tengah dengan tujuan mengidentifikasi bentuk dan pola perundungan di dalam lingkungan persekolahan di Kabupaten Maluku Tengah; sebagai data awal untuk merencanakan tindak lanjut prefentif. Metode pelaksanaan dilakukan melalui penyuluhan dengan kombinasi aktivitas permainan serta wawancara personal serta diakhiri dengan pelantikan Duta Anti Perundungan. Hasil kegiatan menunjukan bahwa berbagai bentuk perundungan terjadi di SMP Negeri 5 Teluk Elpaputih kerap terjadi perundungan, kebanyakan tidak ditangani dengan baik, dibiarkan oleh warga sekolah karena dianggap sebagai kewajaran dan bisa diselesaikan sendiri oleh siswa.
\end{abstract}

Kata Kunci: perundungan, lingkungan persekolahan.

Abstract: Bullying occurs in the school environment, whether done consciously or unconsciously, whether planned or not. In the Maluku, this is also preserved by the existence of the "basengaja" culture as a prerequisite for acceptance in the social environment, including the school environment in Central Maluku. Thus, this Community Service Program was carried out at SMP Negeri 5 Teluk Elpaputih, Central Maluku Regency to identify the forms and patterns of bullying in the school environment in Central Maluku; as initial data to plan preventive actions. The method of implementation is carried out through counseling with a combination of game activities and personal interviews and ends with the inauguration of the Anti Bullying Ambassador. The results of the activity showed that many forms of bullying occurred at SMP Negeri 5 Teluk Elpaputih there was often bullying, most of which were not handled properly, were ignored by the school community because they were considered normal and could be resolved by the students themselves.

Keywords: bullying, school environment.

\section{PENDAHULUAN}

Perundungan atau bullying adalah salah satu fakta penting dalam dunia Pendidikan di Indonesia. Dalam berbagai kajian tentang mutu Pendidikan, ketiadaan perundungan dianggap sebagai suatu indikator penting untuk mengukur mutu sekolah. Oleh sebab itu, dalam Instrumen Akreditasi Satuan Pendidikan Tahun 2020 (IASP 2020), penanganan terhadap perundungan di lingkungan persekolahan menjadi salah satu komponen penting untuk mengukur mutu lulusan sekolah.

Sehubungan dengan itu, data Komisi Perlindungan Anak Indonesia (KPAI) telah menunjukkan kekerapan perilaku kekerasan dan perundungan di dunia pendidikan. Sebagai gambaran, berdasarkan data 30 Mei 2018, sebanyak 161 kasus terjadi dengan rincian: tawuran sebanyak 23 kasus atau 14,3 persen, anak pelaku tawuran 
sebanyak 31 kasus atau 19,3 persen, anak korban kekerasan dan perundungan sebanyak 36 kasus atau 22,4 persen, anak pelaku kekerasan dan perundungan sebanyak 41 kasus atau 25,5 persen, dan anak korban kebijakan (pungli, dikeluarkan dari sekolah, tidak boleh ikut ujian, dan putus sekolah) sebanyak 30 kasus atau 18,7 persen (Nurita, 2018). Secara komprehensif, KPAI mencatat dalam kurun waktu tahun 2011 sampai 2019, ada 37.381 pengaduan kekerasan terhadap anak. Berdasarkan angka tersebut teridentifikasi sebanyak 2.473 laporan $(6,6$ persen $)$ menyangkut perundungan. Menurut Jasra Putra (2020), kecenderungan ini terus meningkat dari waktu ke waktu.

Data tersebut menunjukkan bahwa perundungan terjadi di lingkungan persekolahan dan dialami peserta didik dalam intensitas yang cukup tinggi. Hal itu bukan saja dilakukan oleh sesama peserta didik melainkan juga oleh guru, orang tua, bahkan masyarakat di sekitar lingkungan persekolahan. Hasil penelitian Azzahra, dkk (2019), menunjukan bahwa intensi pelaku melakukan perundungan adalah perasaan ingin dihargai, diperlakukan adil, diperhatikan, serta melalui perundungan subjek merasakan kepuasan. Perundungan merupakan salah satu cara melampiaskan keinginan- keinginan para pelaku. Oleh karena itu, pihak korban perundungan adalah yang dirugikan secara kejiwaan sehingga memengaruhi aktivitas belajar di sekolah. Karena berkaitan dengan kepuasan pelaku, maka perundungan, boleh jadi, akan terus terjadi meskipun terjadi pergeseran generasi peserta didik dalam suatu lingkungan persekolahn.

Dalam konteks daerah Maluku, sebagaimana telah cukup lama diamati secara empiris pada berbagai kalangan, terdapat sebuah kebiasaan yang telah membudaya, yaitu, basengaja. Kebiasaan ini sesungguhnya adalah istilah lokal untuk kata 'bercanda' atau 'bersenda gurau'. Kebiasaan yang menjadi budaya basengaja bukan hanya berwujud bercanda dalam arti sebenarnya, tetapi berujung pada perundungan fisik dan verbal. Banyak anak secara terpaksa harus menerima dirundung dan tidak melakukan apapun untuk melindungi diri sendiri. Pola interaksi pada lingkungan persekolahan sedemikian rupa diasumsikan telah membentuk jejaring perundungan yang diterima sebagai kewajaran selama bertahun-tahun.

Berdasarkan realitas di atas, pemberantasan perundungan di lingkungan persekolahan di

Maluku merupakan wacana yang berkontradiksi dengan kenyataan kultural dalam lingkungan sosial di wilayah Kepulauan Maluku. Pihak sekolah maupun masyarakat dan pemangku kepentingan lainnya selama ini terkesan menganggap hal itu sebagai kebiasaan normatif. Hal itu dibuktikan dengan ketiadaan satu pun data laporan resmi mengenai perundungan yang dapat dijadikan sebagai acuan, meskipun berdasarkan pengamatan, hal itu terjadi secara massif di lingkungan persekolahan. Hal itu dapat diasumsikan lebih lanjut sebagai kecenderungan untuk menganggap perundungan sebagai kewajaran, yang karena merupakan bagian dari kebiasaan dan budaya dalam pergaulan setempat, sehingga tidak akan membawa dampak negatif bagi siswa, baik selama mereka bersekolah maupun sesudah lulus sekolah dan melanjutkan ke jenjang yang lebih tinggi, atau saat memperoleh pekerjaan di masa depan.

Berdasarkan latar belakang ini, kegiatan Pengabdian Kepada Masyarakat (PKM) ini dilaksanakan di SMP Negeri 5 Teluk Elpaputih dengan tujuan untuk mengidentifikasi keberadaan praktik perundungan sebagai data awal untuk merencanakan tindak lanjut prefentif jangka pendek pada saat bersamaan mauun tindak lanjut preventif jangka panjang melalui kegiatan penelitian dan pengabdian kepada masyarakat lainnya.

\section{METODE}

Metode pelaksanaan dilakukan melalui penyuluhan dengan kombinasi aktivitas permainan serta wawancara personal serta diakhiri dengan pelantikan Duta Anti Perundungan. Pada praktiknya, siswa dikumpulkan dalam suatu rombongan belajar. Setelah itu, pemateri akan memberikan pengantar tentang perundungan dalam lingkungan persekolahan dengan menayangkan video dan menjelaskan hakikat perundungan dan efeknya terhadap siswa dan lingkungan belajar secara ringkas dan komprehensif. Selanjutnya, peserta diminta untuk 
mendata kata-kata, frasa, dan kalimat, yang sering ditujukan kepada mereka oleh orang lain, baik di lingkungan sekolah maupun di lingkungan rumah tangga. Setelah peserta selesai mengidentifikasi kata-kata, frasa, dan kalimat secara tertulis, mereka diminta untuk menuliskannya pada papan tulis yang tersedia. Setelah itu, mereka diminta untuk menjelaskan di hadapan seluruh peserta, perasaan mereka terhadap kata-kata yang mereka identifikasi pada saat dilontarkan oleh orang lain. Pada akhirnya, peserta yang menunjukkan reaksi yang di luar harapan, misalnya menolak untuk ikut serta, menangis, atau menunjukkan reaksi ekstrem lainnya akan didekati secara personal melalui wawancara mendalam untuk indentifikasi lanjutan oleh pemateri lain yang berfungsi sebagai tutor.

Kegiatan ini dilaksanakan dalam waktu 3 jam penyajian (@50 menit) meliputi tahap perkenalan, orientasi singkat, penyajian materi, aktivitas kelompok, wawancara, ikrar, serta kesimpulan dan penutup. Pengumpulan data dilakukan dengan menggunakan alat tulis sebagai instrumen. Sedangkan dokumentasi kegiatan sebagai data awal untuk tindak lanjut dilakukan dengan menggunakan kamera dan perekam suara, serta naskah laporan kegiatan. Materi kegiatan meliputi konsep-konsep perundungan dalam konteks budaya basengaja di lingkungan persekolahan dan rumah tangga dengan video yang dipersiapkan oleh pemateri yang berisi contoh-ontoh kasus untuk menghela pemahaman dan membentuk orientasi awal siswa tentang tujuan kegiatan. Alat bantu kegiatan lain yang digunakan adalah laptop dengan aplikasi pemutar video, pengeras suara, serta proyektor untuk menampilkan materi di layar.

\section{HASIL DAN PEMBAHASAN}

Bullying adalah perilaku siswa yang berlebihan, monoton, dan destruktif. Ada berbagai bentuk intimidasi, seperti menyebut nama, memukul atau mengancam orang lain dan menyebarkan rumor palsu. Menurut National Association of School Psychologists (2012), jejaring sosial dan pengiriman teks dianggap sebagai bentuk utama bullying. Mereka yang secara langsung atau tidak langsung terlibat dalam penindasan memiliki risiko lebih tinggi untuk berperilaku buruk, pelecehan, dan ketidakhadiran dari sekolah. Dengan demikian, penindasan menciptakan hambatan untuk belajar dengan hasil negatif di pihak siswa dan institusi. Siswa mungkin menjadi lebih keras dan beberapa waktu bertindak sebagai penindas sesuai dengan situasi.

Bullying di kalangan pelajar tidak hanya menurunkan prestasi akademisnya tetapi juga menyebabkan gangguan kesehatan mental dan cedera fisik. Penindasan mungkin merujuk pada situasi "dilecehkan" oleh orang lain. Ini terjadi pada berbagai jenis ancaman, pelecehan, pelecehan, penganiayaan, dan viktimisasi yang berulang-ulang terjadi (Jan, dkk, 2015).

Perundungan adalah istilah bahasa Indonesia untuk bullying. Sebelum istilah perundungan ini menjadi istilah yang mulai lazim digunakan, kata mengolok, mengejek, mengerjai adalah kata-kata yang telah lebih dahulu digunakan untuk menjelaskan tindakan yang sedemikian. Muliani \& Pereira (2018) dalam Mayasari, dkk (2019) menyatakan bahwa perundungan merupakan penyalahgunaan kekuasaan yang berkelanjutan dalam suatu hubungan, melalui perilaku verbal, fisik, dan/atau sosial yang berulang yang menyebabkan kerugian fisik dan/atau psikologis. Pada sisi yang lain, Glew, Rivara, dan Feudtner (2007) menyimpulkan bahwa perundungan merupakan bentuk agresi di mana satu atau lebih anakanak bermaksud untuk menyakiti atau mengganggu anak lain yang dianggap tidak mampu membela diri. Perundungan dalam bentuk apapun atau karena alasan apapun dapat memberi efek jangka panjang pada mereka yang terlibat, termasuk penonton atau siswa yang menyaksikan secara langsung tindak perundungan tersebut.

Kegiatan PKM dengan judul Identifikasi Perundungan sebagai Wujud Komunikasi

Negatif di SMP Negeri 5 Teluk Elpaputih dilakukan pada tanggal 18 Januari 2020, pukul 09-12 WIT. Kegiatan diikuti oleh 32 orang perwakilan siswa yang berasal dari kelas VII, VIII, dan IX. Kegiatan dimulai dengan tahap perkenalan, kemudian diikuti dengan orientasi 
singkat, penyajian materi, aktivitas kelompok, wawancara, ikrar, serta kesimpulan dan penutup.

Materi tentang perundungan sebagai wujud komunikasi negatif dalam konteks budaya disajikan dengan diselingi pemutaran video berisi bahan pendukung materi. Setelah itu, siswa menulis kata-kata yang dapat diidentifikasi sebagai kata-kata/frasa umum yang digunakan sebagai media perundungan oleh orang lain terhadap mereka. Data yang diperoleh disajikan dalam tabel, sebagai berikut:

Tabel 1. Daftar Kata/Frasa Perundungan Hasil Identifikasi Siswa

\begin{tabular}{|c|c|c|c|}
\hline $\begin{array}{l}\text { Kode } \\
\text { Siswa }\end{array}$ & Daftar Kata/Frasa & Makna & Keterangan \\
\hline 01 & $\begin{array}{l}\text { Gigi boneng, } \\
\text { karibo, badaki }\end{array}$ & $\begin{array}{l}\text { Gigi tonggos, rambut } \\
\text { keriting, kotor }\end{array}$ & \\
\hline 02 & Rambu karibo, empeng & $\begin{array}{ll}\text { Rambut } & \text { keriting, } \\
\text { kerempeng } & \end{array}$ & \\
\hline 03 & Jawa, panoso & Jawa (etnis), pesek & \\
\hline 04 & Itam bakula & $\begin{array}{l}\text { Hitam berdebu } \\
\text { (muka/tubuh/warna kulit) }\end{array}$ & \\
\hline 05 & Karibo, muka hitam & Keriting, wajah/kulit hitam & \\
\hline 06 & Kaki babintang, karibo & Kudisan, keriting & \\
\hline 07 & Muka hitam & Kulit/wajah hitam & \\
\hline 08 & Sarimi, muka itam & Sarimi (merk mi instan), & \\
\hline 09 & Muka itam & Kulit/wajah hitam & \\
\hline 10 & Cipit, ayam saigon, cina & $\begin{array}{l}\text { Sipit, ayam saigon (ayam } \\
\text { dengan buklu jarang, } \\
\text { digunakan untuk menyebut } \\
\text { sesorang dengan rambut } \\
\text { jarang), Cina (etnis) }\end{array}$ & \\
\hline 11 & Karbou inja, karibo & $\begin{array}{l}\text { Pesek (hidung diinjau } \\
\text { kerbau), keriting }\end{array}$ & \\
\hline 12 & Sule, gigi mantega & $\begin{array}{l}\text { (mirip) Sule (pelawak), gigi } \\
\text { berwarna kuning (seperti } \\
\text { mentega) }\end{array}$ & \\
\hline 13 & $\begin{array}{l}\text { Muka hitam badaki, } \\
\text { gendut, baner }\end{array}$ & $\begin{array}{l}\text { Kulit/wajah hitam berdebu, } \\
\text { gendut, balok kayu } \\
\text { (metafora untuk gendut) }\end{array}$ & \\
\hline 14 & - & & $\begin{array}{l}\text { Tidak } \\
\text { mengisi }\end{array}$ \\
\hline 15 & Abarang, karibo & $\begin{array}{l}\text { Abraham (nama Ayah), } \\
\text { rambut keriting }\end{array}$ & \\
\hline 16 & $\begin{array}{l}\text { Rambu strika, kawat, } \\
\text { karibo, ibo }\end{array}$ & rambut keriting & \\
\hline 17 & Itam badaki & Kulit/wajah hitam, kotor & \\
\hline 18 & Muka hitam & Kulit/wajah hitam & \\
\hline 19 & Gigi tarasi & $\begin{array}{l}\text { Gigi berwarna coklat karena } \\
\text { plak/karang gigi/gigi rusak }\end{array}$ & \\
\hline 20 & Karempeng tulang ayam & $\begin{array}{l}\text { Kurus (tulang ayam adalah } \\
\text { perumpamaan) }\end{array}$ & \\
\hline 21 & - & & $\begin{array}{l}\text { Tidak } \\
\text { mengisi }\end{array}$ \\
\hline 22 & - & & $\begin{array}{l}\text { Tidak } \\
\text { mengisi }\end{array}$ \\
\hline 23 & Muka hitam & Kulit/wajah hitam & \\
\hline 24 & Panoso, noko-noko & Rambut keriting & \\
\hline 25 & Itam badaki & Kulit/wajah hitam & \\
\hline 26 & Tai ingos, karibo & Ingusan, rambut keriting & \\
\hline
\end{tabular}




\begin{tabular}{|c|l|l|l|}
\hline 27 & Muka itam, muka tarbai & $\begin{array}{l}\text { Kulit/wajah hitam, wajah } \\
\text { jelek }\end{array}$ & \\
\hline 28 & - & & $\begin{array}{l}\text { Tidak } \\
\text { mengisi }\end{array}$ \\
\hline 29 & Karibo, karempeng & Keriting, kurus & \\
\hline 30 & Itam badaki & Kulit/wajah hitam kotor & \\
\hline 31 & Muka tarbai, karibo & Jelek, keriting & \\
\hline 32 & Muka hitam & Kulit/wajah hitam & \\
\hline
\end{tabular}

Berdasarkan sebaran temuan kata-kata dan frasa yang dirangkum dari respons siswa, ditemukan bentuk-bentuk perundungan, yakni:

1. Perundungan dengan menggunakan identitas etnis; misalnya, penyebutan seseorang dengan mengidentifikasi suku/ras seperti Jawa dan Cina sebagai bentuk olok-olokan;

2. Perundungan dengan mengeksploitasi keadaan fisik; misalnya: menyebut seseorang hitam, keriting, kurus, dll, sebagai bentuk olok-olokan;

3. Perundungan dengan menggunakan nama orang tua; misalnya: menggunakan nama orang tua untuk mengidentifikasi teman/siswa lain. Hal ini, oleh siswa yang menjadi objek identifikasi, dianggap sebagai perbuatan kurang menyenangkan sehingga dapat dikategorikan sebagai perundungan.

Di antara tiga bentuk perundungan yang ditemukan, bentuk yang paling sering muncul adalah bentuk perundungan dengan mengeksploitasi keadaan fisik. Berdasarkan pengamatan dan wawancara pada sesi kegiatan, beberapa siswa menceritakan bahwa mereka merasa sangat tidak nyaman dengan perundungan yang mengeksploitasi keadaan fisik mereka sehingga semuanya menganggap bahwa merundung adalah perbuatan yang harus dihilangkan, baik di lingkungan persekolahan maupun lingkungan rumah tangga dan pergaulan. Dalam hal ini, mereka menyatakan bahwa mereka sering merasakan ketidaknyamanan yang sulit diungkapkan ketika mereka menerima/mendengar kata-kata atau frasa-frasa tersebut ditujukan kepada mereka oleh orang lain namun sering tidak bisa melakukan apapun untuk mencegah atau bahkan sekadar memberi tahu tentang efek buruk perundungan bagi mereka karena takut akan diperlakukan lebih buruk serta dikeluarkan dari lingkaran pertemanan.

Hasil kegiatan ini secara aklamasi berupa tekad preventif untuk mencegah perundungan. Semua peserta pada hari itu telah mengucapkan janji untuk menjadi Duta Anti Perundungan yang akan bertugas di lingkungan tenpat mereka tinggal dan berinteraksi sehingga dapat berdampak secara simultas dalam pemberantasan perundungan. Seluruh peserta bertekad untuk mengomunikasikan secara terbuka semua perasaan mereka saat menerima perlakukan perundungan dengan harapan bahwa kesadaran terhadap perundungan semakin menguat di lingkungan masing-masing.

\section{KESIMPULAN}

Hasil kegiatan menunjukkan bahwa perundungan terus terjadi di lingkungan persekolahan, termasuk di SMP Negeri 5 Teluk Elpaputih. Fakta tersebut ditunjukkan oleh data yang disampaikan oleh para peserta kegiatan berupa data kata/frasa yang sering ditujukan kepada mereka, yang diasumsikan sebagai tindakan perundungan. Perundungan yang terjadi di SMP Negeri 5 Teluk Elpaputih, Kabupaten Maluku Tengah, ditemukan dalam 2 bentuk, yakni (1) Perundungan dengan menggunakan identitas etnis; (2) Perundungan dengan mengeksploitasi keadaan fisik, dan: (3) Perundungan dengan menggunakan nama orang tua. Semua peserta mengucapkan kredo untuk menjadi Duta Anti Perundungan di lingkungan masing-masing.

Lebih lanjut, mayoritas siswa menunjukkan ketidakberdayaan utuk mencegah dirundung oleh sesama teman karena hal itu dianggap sebagai kebiasaan/kewajaran, serta tidak banyak mendapat perhatian/tindakan preventif dan kuratif dari orang tua atau guru. Dengan demikian, pemberantasan perundungan di lingkungan pendidikan/persekolahan dengan model seperti ini dapat dilakukan di sekolah pada wilayah yang lain. Hal ini dimaksudkan untuk 
mendapatkan gambaran yang lebih jelas dan utuh tentang perundungan di lingkungan persekolahan maupun lingkungan lainnya tempat siswa berinteraksi dalam relasi sosial.

\section{REFERENSI}

Toharudin, Toni, dkk. 2020. Instrumen Akreditasi Satuan Pendidikan 2020 (IASP2020). Jakarta: BAN S/M.

Dewi Nurita, D. (2018, Juli 23). Hari Anak Nasional, KPAI Catat Kasus Bullying Paling Banyak. Tempo. Diakses pada: https://nasional.tempo.co/ read/1109584/ hari-anaknasional-kpai- catat-kasus-bullying-paling-banyak/full\&view=ok, tanggal 12 Oktober 2020, pukul 17.44.

Putra, Jasra. (2020). Sejumlah Kasus Bullying Sudah Warnai Catatan Masalah Anak di Awal 2020, Begini Kata Komisioner KPAI. Diakses pada : https://www.kpai.go.id/berita/sejumlahkasus-bullying-sudah-warnai-catatan-masal ah-anak-di-awal-2020-begini-katakomisioner-kpai, tanggal 12 Oktober, pukul 18.04.

Azzahra, Aning, dkk. (2019). Intensi Pelaku Perundungan (Bullying): Studi Fenomenologi pada Pelaku Perundungan di Sekolah. Dimuat dalam Jurnal Psycho Idea (daring), Volume 17 Nomor 1, Tahun 2019, e- ISSN 2654-3516. Diakses pada http://jurnalnasional.ump.ac.id/ index.php/PSYCHOIDEA/ article/view/3849.

Mayasari, Amiirohana, dkk. (2019). "Tindak Perundungan di Sekolah Dasar dan Upaya Mengatasinya". Dimuat dalam Jurnal Pendidikan: Teori, Penelitian, dan Pengembangan e-ISSN 2502-471X, Volume: 4 Nomor: 3 Bulan Maret Tahun 2019 Halaman:399-406. Diakses pada http://journal.um.ac.id/index.php/ jptpp/article/view/12206/5727, 20 Oktober 2020, pukul 22.13.

Jan, Afros dan Shafqat Husain.(2015). "Bullying in Elementary Schools: Its Causes and Effects on Students." Dimuat dalam Journal of Education and Practice, ISSN 2222-1735 (Paper) ISSN 2222-288X (Online), Vol.6, No.19, 2015, diakses pada 20 Oktober 2020, pukul 22.35.

Maunder, Rachel dan Sarah Crafte. (2018). "School bullying from a sociocultural perspective." Dimuat dalam e-jurnal Aggression and Violent Behavior Volume 38, Januari-Februari 2018, Pages 13-20. Diakses pada laman https://www.sciencedirect.com/ science/article/pii/ S1359178917302082\#!, tanggal 20 Oktober 2020, pukul 23.55.

Murkowski, W. M., Sipploa , L.K., \& Newcomb, A. F. (2001). Variations in patterns of attraction to same-and other-sex peers during early adolescence. Developmental Psychology, 36, 147-154. 